\title{
Mothers, Grandmothers, Patriots. Religious Imageries of Female Members of the Confraternity of the Infant Jesus at the Church of St Wojciech and St Stanisław in Rzeszów, Poland ${ }^{1}$
}

\author{
Magdalena Lubanska \\ Institute of Ethnology and Cultural Anthropology \\ University of Warsaw \\ magdalena.lubanska@gmail.com
}

\begin{abstract}
This paper presents the findings of ethnographic field research focusing on the worship of the Christ Child as practised by female members of a Fraternity of the Infant Jesus in the main church (kościót farny) in the city of Rzeszów in south-eastern Poland. Based on anthropological analysis of secondary sources and primary data collected through interviews, I try to answer the question of why the women choose to worship God as a Child, and how their choice is connected with their spiritual path. What kind of figures do they embrace as spiritual role models, and why? What is it about the worship of the Child Jesus that they find attractive, and how do they maintain, and contribute to, that form of worship? I will connect these aspects of the worship to women's strong need for "giving/protecting life" as well as for sensual relationship with the sacred. I treat this need as a self-embraced development strategy combining a fulfilled feminine identity with a religious life as worshippers of Christ.
\end{abstract}

Keywords: Christ Child, religious imageries, women, Rzeszów, life, childhood, old age

Słowa kluczowe: Dzieciątko Jezus, religijne imageria, Rzeszów, kobiety, dziecięctwo, starość

\section{Introduction}

This article is based on an ethnographic field trip made in May 2015 to the Polish region of Subcarpathia (Polish: Podkarpacie). Among other locations, my itinerary included the Bernardine church in Rzeszów, where my attention was immediately

${ }^{1}$ Funding for this project came from the Polish National Science Centre, decision no. DEC2013/11/B/HS3/01443. 
drawn to an elderly woman who was praying in front of the image of Our Lady of Rzeszów. The woman looked focused and lost in prayer. I approached her outside the church, and it soon became clear that I was dealing with a highly devout person who was dedicated to promoting devotion to the Infant Jesus in the city's oldest parish church, the church of St Wojciech and St Stanisław in Rzeszów. According to the woman, the direct impulse for this project ${ }^{2}$ came to her during a pilgrimage she had made to locations connected with St Thérèse of Lisieux in 2008 as a leader of a local group of a Catholic organisation known as the Family of the Scapular. Among other locations, the pilgrims visited the church of Our Lady Victorious in Prague. In her own words, the minute she saw the local figurine of the Infant Jesus of Prague, "[she] just couldn't get it out of [her] thoughts. [She] simply had to have one in her own parish as well." On her return to Rzeszów, she immediately launched an effort to promote devotion to the Infant Jesus in the city's oldest parish church.

Exploring a form of devotion that arose from a pilgrimage seemed like an intriguing research project. What was particularly interesting about it was the fact that it was an instance of multisensory Catholic imageries in Polish Subcarpathia, that is to say somatic and discursive expressions of imageries related to the religious sphere. In common with Pierre Bourdieu and Thomas Csordas, I believe that the socially informed body provides the fundamental underpinning of such imageries. ${ }^{3}$ My interest was also piqued by the fact that devotion to the Infant Jesus remains an underresearched aspect of Catholic devotion in Poland, even though this particular form captures many aspects of Polish Catholicism among women in that it reveals "how forms of 'divine' kinship shape gendered imagination, horizon of motherhood, the messianism of the Polish nation-state, and the contested domain of distribution of life and death around the unborn foetus." ${ }^{\prime 4}$ This form of worship, which confers a privileged status on women past child-bearing age, expresses a certain form of kinship and "ontological proximity" with the sacred. The women experience that closeness or proximity by choosing to worship Jesus as a cuddly Infant, whom they perceive as more approachable and more likely to hear their prayers compared to the altogether more sombre figure of the crucified, suffering Jesus. In gazing at the Child, they develop a particular kind of maternal relationship. Their belief that the Child listens to their prayers gives them a sense of agency, and makes them feel like important members of society.

Based on anthropological analysis of secondary sources and interviews with female members of the Confraternity of the Infant Jesus in that church, I try to formulate answers to a series of questions: why do my respondents worship God in the form of an infant? What kind of figures do they embrace as role models in their spiritual life, and why? What makes this form of devotion attractive to them, how do they practise it and how are they involved in its maintenance?

\footnotetext{
${ }^{2}$ I will be using the term "the Infant Jesus" in reference to the official forms of spirituality, and "the Baby [Jesus]" or "the Child [Jesus]" when quoting my respondents.

${ }_{3}$ T. Csordas, Body/Meaning/Healing, New York 2002, p. 63; P. Bourdieu, Outline of a Theory of Practice, Cambridge 1977, p. 72.

${ }^{4} \mathrm{I}$ am quoting my anonymous peer reviewer.
} 
To place these questions as well as my primary material within a broader context, a note of introduction is in order to explain the historical background. Devotion to the Infant Jesus is a form of worship of some historical standing in Subcarpathia, in both religious and secular communities in the region. A brief survey of its origins follows.

\section{Devotion to the Infant Jesus - a brief historical outline}

As a prelude to a more detailed account of the devotion to the Infant Jesus in Rzeszów's oldest parish church, this brief outline explains its origins and provides details of some of the most important historical figures who contributed to this form of devotion. The following names were often mentioned by my respondent, Irena, and her fellow members in their comments and explanations.

In the New Testament, veneration of Jesus as a child can be traced back to the evangelical scenes of adoration by the Magi and the shepherds after the birth of Jesus. St Simeon and St Anne are likewise traditionally regarded as some of the earliest worshippers of the Infant Jesus. In church liturgy, this form of veneration primarily takes place at Christmas, and dates back to the fourth century.

Relatively detailed attention is paid in the Gospels to the place and circumstances of Jesus's birth. Jesus's childhood, on the other hand, is relatively overlooked in Scripture. The only references in the Gospels concern the fact that Jesus assisted his father in his work, and another incident where Jesus got lost during a pilgrimage to Jerusalem at the age of twelve. More detailed accounts of Jesus as a young child exist in some apocrypha, including the Infancy Gospel of Thomas, the Georgian Gospel, the Protoevangelium (Infancy Gospel) of James, the Gospel of Pseudo-Matthew and the Armenian Gospel of the Infancy.

In Catholicism, important contributions to the veneration of Jesus's childhood came in the thirteenth century from St Francis of Assisi, who introduced the tradition of Christmas nativity scenes open to public veneration.

Devotion to the Infancy of Jesus was simultaneously developing in Carmelite monasteries, and this form of worship has evident associations with that spiritual tradition. ${ }^{5}$ According to a Carmelite legend, the earliest figurine of the Infant Jesus was made around the late eleventh/early twelfth centuries in a monastery in southern Spain, where a local monk named Joseph with a special veneration for the Infant Jesus and the Holy Family received a vision of the Infant, and made its likeness out of wax. ${ }^{6}$ The Catholic Church also acknowledges the major contributions made to this form of spirituality by Carmelites such as St Teresa of Ávila and St John of the Cross. St Teresa of Ávila was apparently never without a figurine of the Infant Jesus; she introduced special devotions to the Infant Jesus as part of her programme of reform for existing Carmelite monasteries, and donated figures of the Infant Jesus

${ }_{5}^{5}$ J.W. Gogola, Duchowość Dzieciątka Jezus u świętych Karmelu [in:] Dzieciatko Jezus w Karmelu. Sesja naukowa z okazji 100. rocznicy erekcji bractwa Dzieciatka Jezus w Krakowie (25.01.2014), J.W. Gogola, Z.K. Dubel (eds.), Kraków 2014, p. 23.

${ }^{6}$ B. Gajewski, T. Pikor, Kult Dzieciatka Jezus w Golcowej, Golcowa 2014, p. 6. 
to newly established monasteries. ${ }^{7}$ The oldest such figurine is kept at Ávila at the monastery of St Joseph, ${ }^{8}$ also known as the Monastery of the Incarnation.

There are also accounts of St John of the Cross dancing with a figurine of the Baby at Christmas in 1585, and mentioning his fondness for celebrations devoted to the Infant Jesus. ${ }^{9}$

Outside of Spain, devotion to the Infant Jesus spread in Carmelite monasteries in France, particularly in the monastery of Discalced Carmelite nuns in Beaune, where the seventeenth-century nun Margaret Parigot (also known as Margaret of the Most Holy Sacrament) followed a request from the Infant Jesus to observe a day of special veneration for the Infant on the twenty-fifth day of each month, and to recite a special chaplet made up of three Our Fathers and twelve Hail Marys (celebrating the first twelve years of Jesus's life). She founded a Family of the Child Jesus, and introduced the idea of a Jesus Month, a celebration lasting from the twenty-fifth day of a given month until the twenty-fifth day of the next. The figurine of the Infant Jesus at Beaune is known as Le Petit Roi de Grâce.

In the seventeenth century, devotion to the Infant Jesus developed in Prague, where a Carmelite monastery and a church of Our Lady Victorious were built in 1642. A Czech noblewoman by the name of Polyxena of Lobkowicz donated a figurine of the Infant Jesus to the monastery (the figurine was probably made in Cordoba). The figurine depicts a four-year-old child wearing a crown. It is carved out of wood and coated in wax, and dressed in royal robes..$^{10}$ The figurine is credited with saving the monastery during a Swedish invasion and a plague epidemic in the seventeenth century.

Sandra La Rocca sees the flourishing of devotion to the Infant Jesus in the seventeenth century as a typically female type of spirituality, which sought to emancipate itself from male intermediaries like Catholic priests. ${ }^{11}$ Later in this article I will draw attention to similar aspects in the context of that form of devotion in Rzeszów.

In the eighteenth century, devotion to the Infant Jesus received a boost from St Thérèse of Lisieux, also known as St Thérèse of the Child Jesus. St Thérèse developed a doctrine of the so-called "little way" (petite voie): a way of spiritual childhood where practitioners were encouraged to cultivate evangelical virtues of humility, simplicity and spontaneity. She represented a sensory-based form of devotion with a generous admixture of childlike imagination. For instance, she liked to think of the corporal cloth used in liturgy as the swaddling clothes of Baby Jesus. ${ }^{12}$

Devotion to the Infant Jesus is also known in Italy, where it is practised in the Carmelite monastery church at Arenzano and in the basilica of Santa Maria in Araoeli in

${ }^{7}$ J.W. Gogola, op. cit., p. 22.

${ }^{8}$ P. Ferko, Mały Król Chwaty z Beane (Francja), http://www.karmel.pl/maly-krol-chwaly/ [access: 31.05.2017].

${ }_{9}$ J.W. Gogola, op. cit., pp. 22-23.

${ }^{10}$ S.T. Praśkiewicz, Kult Dzieciątka Jezus w polskim karmelu reformowanym [in:] Dzieciatto Jezus w Karmelu..., op. cit., Kraków 2014, pp. 35-36.

${ }^{11}$ Cited in: I. Kuźma, Wspótczesna religijność kobiet. Antropologia doświadczenia, Poznań 2008, p. 200.

${ }^{12}$ Św. Teresa od Dzieciątka Jezus, Dzieje duszy, Kraków 1984, p. 171. 
Rome. ${ }^{13}$ In Poland, the earliest confraternities of the Infant Jesus were established in the first half of the seventeenth century, probably as branches of the Beaune confraternity, but the evidence is very patchy. ${ }^{14}$ We have more information about confraternities established later in the nineteenth and twentieth centuries. In 1897, a group was established at the monastery of the Discalced Carmelite nuns in Kraków, followed by another one in the same city at the Monastery of Discalced Carmelite monks of the Immaculate Conception in 1914. ${ }^{15}$ Further confraternities were established at Discalced Carmelite monasteries at Wadowice, Lublin, Czerna, Łódź, and Przemyśl.

Poland's most assiduous promoter of devotion to the Infant Jesus was Father Anzelm Gądek, a Discalced Carmelite monk who lived in the monastery at Czerna. $\mathrm{He}$ was involved in the establishing of a confraternity in Kraków, and translated a special prayer service to the Infant Jesus known as the Way of Bethlehem. The service was modelled on a German text written in Austria. Celebrated on the twenty-fifth day of each month, it was also known at the confraternity of the Infant Jesus in Rzeszów. Together with a female member of the confraternity he headed (a secular tertiary named Janina Kierocińska), Father Gądek established a non-enclosed religious congregation of the Carmelite Sisters of the Child Jesus, and donated to it the first figurine. Janina Kierocińska became the congregation's first superior in 1921, for which she developed a variety of sensory-based forms of devotion, including the practice of hanging symbolic representations of the congregation's needs from the arm of the figurine during the difficult wartime months (for instance, when coal was in short supply the sisters hung a piece of coal from the figurine's hand; when looking for money or a new house, they used a coin or a little house made of cardboard). ${ }^{16}$ The sisters also practised fervent prayer, and their superior, Sister Janina Kierocińska, often said to them, "May the Divine Child give you solace, courage and strength to deal with your ordeals." ${ }^{17}$ The sisters modelled their lives on St Thérèse of the Child Jesus. Today, houses of the congregation are active in Poland in Łódź, Toruń, Zakopane, Gołkowice, Przysietnica, Kroczyce, Sosnowiec, Niegowić, and Gorczyce.

In the region of Subcarpathia, devotion to the Infant Jesus also takes on a more secular aspect. In addition to the church of St Wojciech and St Stanisław in Rzeszów, this form of devotion is also known in the towns of Jodłowa, Golcowa, and Zagórze. At Golcowa, devotion to the Infant Jesus was promoted around the turn of the twentieth century by Maria Śmigiel, who purchased a figurine of the Infant Jesus in Kraków or Prague around the year 1920, and venerated it at home. The figurine was credited with saving her village from a fire. When she received a dream vision from the Child, requesting to be placed among his people, Śmigiel raised funds locally, and bought a larger figurine (some two feet in height) wearing a crown. That larger

13 B. Gajewski, T. Pikor, op. cit., p. 8.

${ }^{14}$ S.T. Praśkiewicz, op. cit., pp. 35-56.

${ }^{15}$ Ibidem, p. 36.

${ }^{16}$ B.B. Batog, Miłość do Dzieciątka Jezus w życiu i działalności czcigodnej stugi Bożej M. Teresy Kierocińskiej [in:] Dzieciątko Jezus w Karmelu..., op. cit., p. 89.

${ }^{17}$ Ibidem, p. 93. 
figurine was placed at the altar of the church at Golcowa, and quickly became famous for healings. ${ }^{18}$

In 1896-1919, the same form of devotion was promoted at Jodłowa by the local parish priest, Fr. Ignacy Zięba, who had learned about it from a friend and fellow priest, a prelate named Józef Wiejawski who was Chancellor of the Diocese Curia at Przemyśl. Fr. Zięba imported a little chapel containing the figurine from a monastery of Carmelite nuns in Przemyśl, and taught his congregation how to recite a prayer service to the Child Jesus. ${ }^{19}$ The devotion soon became popular in the area, and the figurine became famous as the Miraculous Figurine of the Child Jesus. Later parish priests retained this tradition. In 1995, work began on construction of a shrine devoted to the Infant Jesus. The church was consecrated in 2008, and the figurine was ceremoniously moved to the new shrine and enthroned there. One of the most important celebrations devoted to the Child Jesus is a period of indulgence beginning with the midnight Christmas or "shepherds" mass" (Pasterka), and ending with the New Year mass. ${ }^{20}$ The shrine is regularly visited by pilgrims.

My respondent, Irena, is well aware of the "competing" figurines of the Infant Jesus of Prague. On the one hand, she "competes" to make sure "her Baby" looks best; on the other, her enthusiasm for this form of devotion can be contagious enough to spread to other locations. She was instrumental in reviving devotion to the Infant Jesus at Golcowa, where a local parish priest actually went on to write a book on the subject. An extended second edition of the book soon followed in 2014.

\section{Post-pilgrimage devotion to the Infant Jesus at the church of St Wojciech and St Stanisław in Rzeszów, and Irena, its initiator}

\section{a) Irena - a "specialist in religious objectification"}

The history of this form of devotion in Rzeszów's oldest church goes back to just seven years ago. As mentioned previously, it was initiated by Irena, a secular Carmelite tertiary and for some ten years a moderator in a Carmelite-affiliated group of the Family of the Scapular, who is currently also a leader in the Confraternity of the Infant Jesus. Irena is about 70 years old, she comes from the town of Dębica, and lives alone in Rzeszów; she has several grandchildren. By her own report, a miraculous survival from a car crash was the turning point in her life. After that experience she re-examined her relationship with God, and became more committed as a Christian. Irena is a fervent believer in the Child Jesus, to whom she entrusts herself and her loved ones at difficult periods in their lives. ${ }^{21}$

\footnotetext{
${ }^{18}$ B. Gajewski, T. Pikor, op. cit., pp. 33-53.

19 J. Kapłon, Historia kultu Dzieciątka Jezus w Jodlowej [in:] Dzieciatko Jezus w Karmelu..., op. cit., p. 134.

${ }^{20}$ Ibidem, p. 138.

${ }^{21}$ Among other stories she told me how she placed a picture of the Infant Jesus on the forehead of her grandchild, who was hospitalised with an acute infection; the fever soon ended and the child recovered.
} 
Irena is the only member of her family involved in devotion to the Infant Jesus, and in Carmelite spirituality more generally. Over the past few years she has managed to set up a confraternity of the Infant Jesus that has around sixty members, including twenty children (the childcare is provided by Felician nuns working in that church). Irena also acknowledges the role of Sister Elwira, a nun who made an important contribution in the setting up of the confraternity before she was relocated to Częstochowa several years ago. Irena and her friend Marta developed a set of education materials for children: a workbook called Maleńka mitość [Tiny Love] containing passages from the Gospel on the childhood of Jesus, and related legends from all over the world. ${ }^{22}$

Irena wrote an account of how devotion to the Infant Jesus began in Rzeszów's oldest church, and had it posted on the parish website ${ }^{23}$ and in several other places. Her texts present the project as the realisation of her own dreams. On the other hand, she portrays it as the fulfilment of a wish from Baby Jesus. "The Infant Jesus of Prague is well pleased with our church, and chose to be worshipped here (...)."

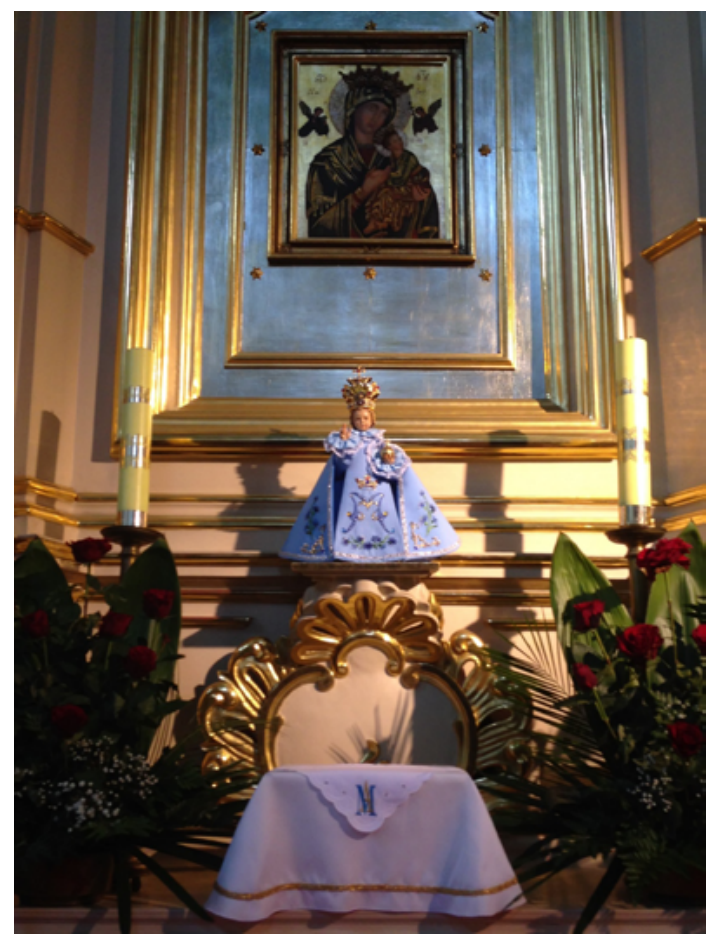

Photograph 1: Figurine of the Infant Jesus of Prague at the church of St Wojciech and St Stanisław in Rzeszów. Photo: M. Lubanska

${ }^{22}$ Maleńka miłość. Kult praskiego Dzieciatka Jezus. Modlitewnik, Kraków 2013; Maleńka mitość. Tajemnice dziecięctwa. Zeszyty formacyjne, Rzeszów 2014.

${ }^{23}$ Kult Praskiego Dzieciątka Jezus, http://www.fara.rzeszow.pl/grupy-duszpasterskie/bractwo-praskiego-dzieciatka-jezus/ [access: 31.05.2017]. 
On Irena's part, these claims about the supernatural origin of this form of worship are an effective form of legitimising it and boosting its stature vis-à-vis the church hierarchy. As she points out, it took considerable effort, persuasion skills and patience to organise this form of worship in the city's oldest church. It was two years before Fr. Stanisław Bełza, the local parish priest at the time, finally gave Irena his official consent to bring a figurine of the Infant Jesus from Prague in April 2010 (a time she describes as "the time before the attack," referring to the plane crash in Smolensk later that month that killed Poland's president and many high-ranking officials), and she went to Prague with two female friends and fellow members of the Family of the Scapular. They made their journey accompanied by the provincial moderator of the Carmelite monastery at Czerna, Fr. Jan Krawczyk.

The women visited a shop in Prague selling devotional articles and looked at a number of figurines, but it was Irena who made the final choice. The figurine was consecrated at the altar of the Infant Jesus of Prague. After the consecration ceremony in Prague, and following a prayer service at Czerna for the establishment of a confraternity of the Infant Jesus in Rzeszów ${ }^{24}$ the figurine was taken to the monastery of Discalced Carmelite nuns, where a crown was added to it, and where another special prayer service was held over a period of three days. The figurine was then taken to the house of the Felician Sisters working at the church of St Wojciech and St Stanisław in Rzeszów for nine more days of prayer. On 30 May 2010, the sisters took the figurine into the church in a ceremonial procession, dressed in white communion robes. After a solemn mass, Fr. Paweł Ferko ${ }^{25}$ blessed the sisters with the figurine, a gesture that became a regular element of services held in that church, where a priest now blesses children at the figurine every Sunday after the mass at 12:15 PM.

At present, the figurine stands at the altar of Our Lady of Perpetual Help. Irena often spends time in prayer before the figurine, praying for other people and major life events. When we met, she took me straight to the figurine, and told me to write a prayer request asking for good research results, and place it on a piece of paper in a nearby box where prayer intentions were being gathered for the Infant Jesus. Perhaps it was her strategy to gain my interest in the subject by demonstrating how serious she was about her devotion to the Infant Jesus. Without a doubt, prayer requests were also a key form practised by Irena of objectivising the Infant. Practices such as gazing at the figurine, praying in front of it, and leaving prayer requests were all intended to forge a close relationship with the Infant Jesus, and to instil a habit of addressing the figurine.

In Thomas Csordas's terminology, Irena can certainly be viewed as a "specialist in religious objectification": a respected member of a community who can manage, distinguish, and classify other people's emotions and reflections. In doing so, she plays a major role in objectivising the models and patterns of a given habitus. ${ }^{26}$

${ }^{24}$ The Confraternity of the Infant Jesus in Rzeszów's church of St Wojciech and St Stanisław was established on 30 March 2012.

${ }^{25}$ The priest became the confraternity's first spiritual director.

26 T. Csordas, op. cit., p. 65. 
Confraternity meetings run by Irena, her texts about the Infant, and the strategies of religious socialisation among the members in the Rzeszów confraternity all influence the religious imageries of the members and the nature of their relationship with the Infant Jesus. Irena knows a number of different ways to make this form of devotion interesting to other women. For instance, she persuaded one current female member to join if she recovered from cancer after prayers to the Infant were held for her recovery. The woman did indeed recover.

In managing the worship of the Infant Jesus, Irena relies on advice offered by Carmelite nuns of the Infant Jesus, and she remains in touch with other monasteries in Zakopane and Łódź. Former locations of this form of devotion in Subcarpathia are an important point of reference for Irena, and that local history made it easier for her to introduce the same practices in Rzeszów, as devotion to the Infant had already been a recognisable element in Subcarpathian religious imageries. In this sense, the worship practices at Rzeszów are part of a broader local tradition, but this also triggers competition. When talking to me, Irena made numerous comparisons between the figurine of the Infant Jesus at her own church and other figurines in the region - especially those at Golcowa and Jodłowa, where this form of devotion goes back more than a century. Irena compares the robes of the figurines, and clearly wants her Infant in Rzeszów to be the most beautiful and most famous for gifts of divine grace. She recounts any gifts that come to her attention in a newsletter. Devotion to the Infant Jesus has become a recognisable element in the city's religious landscape, and shops selling devotional products now also carry figurines of the Child. As a result, Irena and many members of the confraternity have their own figurines at home.

I suppose that Irena's commitment to promoting this form of devotion in Rzeszów is based not only on the Infant Jesus of Prague, but also on her personal fascination with other key figures in that form of worship, including Maria Śmigło of Golcowa, St Thérèse of Lisieux, and Margaret of the Blessed Sacrament. Irena sees herself as part of a line of women chosen by the Infant Jesus to spread his glory. Irena chose St Thérèse of Lisieux as the confraternity's spiritual patron, and asked Sister Konrada, a Carmelite nun, to help her bring the saint's relics to her church in Rzeszów. My conversations with other members of the confraternity suggest that St Thérèse is an important figure for them as well.

From the very beginning, Irena made efforts to keep a record of the worship of the Infant Jesus, and she has been chronicling the developments at her church in Rzeszów. Not unlike doting parents who record a child's milestones in a photo album, she has been adding photographs to her chronicle to document important events relating to the figurine, beginning with its consecration in Prague, and including a series of prayer services at the church of St Wojciech and St Stanisław in Rzeszów. She presented a paper on devotion to the Infant Jesus in a scholarly panel on "The Infant Jesus at Carmel," which was published in a book of the same title (2014). Irena and her assistant and biological sister, Marta, prepare copy for their newsletter, Maleńka milość [Tiny Love], which the confraternity publishes twice a year. The title page always features a photograph of the Rzeszów figurine. The two women have also created a prayer book with the same title. 


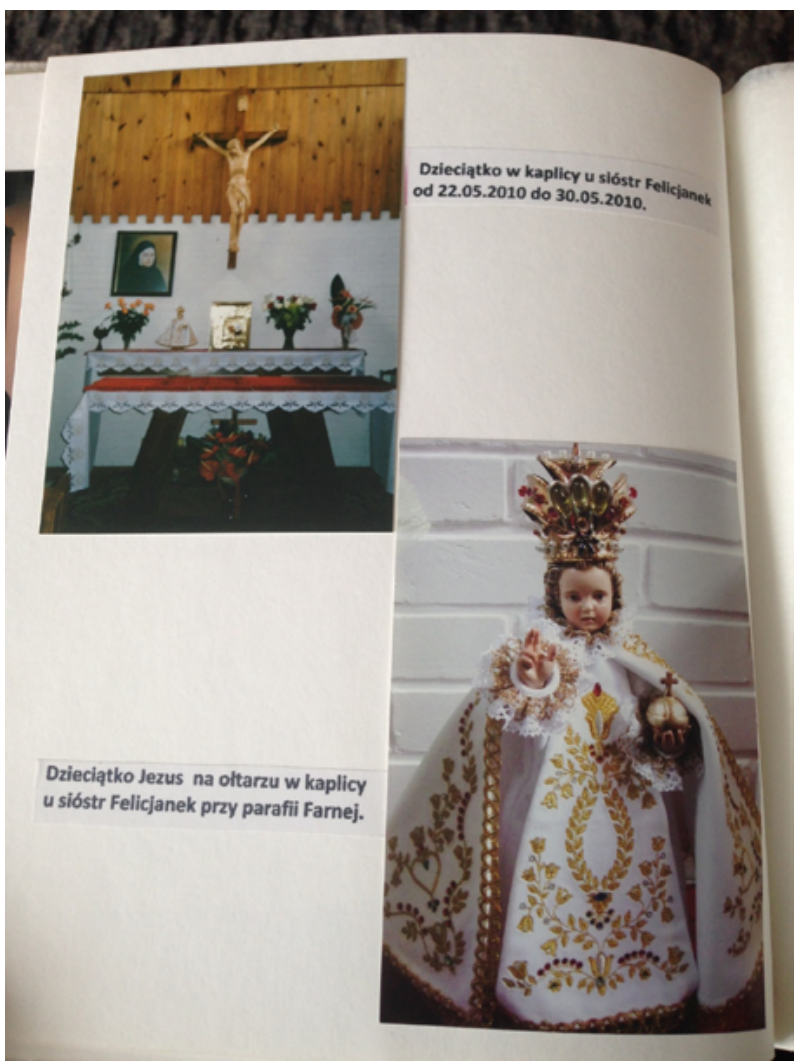

Photograph 2: A page from the photo album where Irena chronicles major events related to the figurine. Photo: Magdalena Lubanska

Irena also keeps a Book of Gifts of Grace in her house, in which she documents the prayer requests left in the special box in the church (which are then read out on the twenty-fifth day of each month during a special novena to the Infant Jesus), as well as testimonies from people who thank the Infant for the gifts of grace they received as a result. Irena claims that around 100 prayer requests are made every month, mostly asking for new pregnancies, recovery from illness or mending of broken family relationships. She allowed me to read some of them: many of the devotees were asking for the grace of motherhood and successful delivery. Irena has this to say about the requests:

There is so much love in the way those requests are addressed to the Baby, it's actually moving, the kind of trust people have. You wouldn't have the same kind of audacity when addressing an adult, compared to a Baby, that kind of thing matters, too. It's hard to say. Obviously, God is everything and [it would be good] if people realised who God is, and instead of just patting God on the shoulder they actually stood before Him as the world's Creator, who holds the world in his hand. 
My respondent finds the figurine's materiality to be more approachable and relatable than Jesus as a grown man. In several interviews she made express mention of her belief that this form of devotion can reach children's hearts, and shape their spiritual development and religious formation:

It's a tangible sign that this is important, that this is a timely form of devotion. Bring the children close to the Baby. Where else do you expect children to gather if not close to the Mother of God and the Baby? (...) I am deeply convinced that the effort to save the faith should begin with children. This is the best form of devotion, to have children gather close to the Baby. For those children to come and look at what one parish priest, an old man, called "such a pretty doll." It's true, it's a pretty thing, it's like that (...). This is why devotion to the Infant Jesus is important, that's how I feel it, and no one understands how you can lead children with the Baby.

On multiple occasions Irena uses the term religious formation, by which she means religious socialisation, and which she regards as a supreme value in life. According to her, religious formation teaches people to live in communities, to choose saints as role models, and to use specialist literature and religious media programming to "live a better life." Her paragons of ideal parenting include the parents of St Thérèse of Lisieux (the patroness of the confraternity), and Robert "Litza" Friedrich and his wife (Friedrich is a composer and rock musician who created Arka Noego, a popular Polish Christian rock band featuring many child performers). She recommended some parenting literature to me, particularly Dobre drzewo ${ }^{27}$ [The Good Tree] and Wilki $d w a$ [The Two Wolves] by Adam Szustak and Robert Friedrich. According to Irena, women who have had a religious formation make better mothers since they are better able to manage their children's development, and to make better mass culture choices compared to women who do not have similar advantages. In this context, Irena mentioned parenting ideas, such as showing children cartoons available on the Polish Catholic television channel (TV Trwam) rather than what she calls "aggressive" children's shows on secular television channels. She also encourages parents to get their children into the confraternity of the Infant Jesus. In this context I agree with the observation made by Roberto Orsi: "Children's bodies, rationalities, imaginations, and desires have all been privileged media for giving substance to religious meaning, for making the sacred present and material, not only for children but through them too, for adults in relation to them." 28 In other words, by watching children as they are worshipping the Infant, devotion to the figurine receives an ontological boost among its principal worshippers, namely the female members of the confraternity. Incidentally, the women often gift figurines of the Infant Jesus to their grandchildren on their own initiative. In doing so, they share with the children something they find to be of great value (the Infant Jesus), but on the other hand their own faith receives

27 The parents of St Thérèse of Lisieux (Zélie and Louis Martin) are spiritual patrons of the Family of the Scapular at the same church in Rzeszów, a group which is likewise moderated by Irena. The Rzeszów church owns relics of St Thérèse of Lisieux and of her parents. W. Kluz, Dobre drzewo. Opowieść o Ludwiku i Zeldii Martin, rodzicach św. Teresy od Dzieciątka Jezus, Kraków 2005.

${ }^{28}$ R. Orsi, Material Children: Making God's Presence Real for Catholic Boys and Girls and for Adults in Relation to Them [in:] R. Orsi, Between Heaven and Earth. The Religious Worlds People Make and the Scholars Who Study Them, Princeton-Oxford 2005, pp. 73-109. 
a boost from this chance to witness the expression of a shared religious imaginary in rituals practised by the children. When correctly moderated, children can often practise a kind of best-practice religiosity that the adults are often incapable of. In Orsi's words, children become a religious "repository of need and desire" for adults. ${ }^{29}$

Irena is not only a committed religious community leader, strategically working to introduce devotion to the Infant Jesus in the city's main church, but she has also shown political involvement. In 2001, she stood for parliamentary election as a member of the right-wing League of Polish Families. Her agency is realised at the level of family (primarily as a grandmother), her parish (as a religious leader), and the nation (as a voter and, at times, political activist).

\section{b) Women's religious imageries focused on the worship of the Infant Jesus in the confraternity in Rzeszów}

When asked how they imagined the Infant Jesus, some female members of the confraternity said that they imagined a child who looked exactly like their figurine, while others spoke of an angelic-looking infant. Some imagine the Child in the manger at Bethlehem, or see Jesus as a toddler. They describe the child in general terms as being "lovely" or simply "looking like a normal child." Some tell apocryphal stories about Jesus's childhood, such as the story of a robber's child who was healed when bathed in Baby Jesus's bathing water:

When the family were fleeing to Egypt, a brigand chief had a child who suffered from leprosy. The Mother of God gave the Baby a bath, and then told the brigand to bathe the child with leprosy in the same water. They did, and the child recovered. $(\mathrm{H})$

They also draw attention to the fact that Jesus's childhood lasted until the age of twelve, the same time he got lost on a pilgrimage to Jerusalem. Members often told a story claiming that the figurine was modelled on the real Child:

It was the Child himself who came to the painter or sculptor who carved that figurine, the Child showed itself, and the figurine is apparently modelled on those visions, if I remember correctly. (J)

One of the female respondents also told stories of the Child Jesus bringing dead birds back to life, and never laughing out loud:

I recall, but I'm not sure if that's just something I saw in a film, I recall that the Lord Jesus could bring dead birds back to life, and that made other mothers look askance on the Most Blessed Mother. I remember since when I was young, I must have read that in Maria Valtorta, that the Lord Jesus never laughed. He never laughed the kind of belly laugh we have, "ha ha ha," he just smiled. (J)

Leaving aside the question of the theological meaning of how the female members perceive divinity in the figurine, I wish to focus on the anthropological question: what is it that makes the worship of the Infant Jesus attractive to those women? What kind of needs does it fulfil? Who are those women? And why are most of the

${ }^{29}$ Ibidem, p. 79. 
members female? On the one hand, we might ask whether this profound relationship with the figurine of the Infant Jesus is not in fact indicative of having what Tanya Luhrmann's concept (combining anthropology and the theory of mind) ${ }^{30}$ calls an imaginary companion. ${ }^{31}$ Do they not, in common with Luhrmann's respondents in some American Evangelical communities, train their minds and bodies to enter into this kind of relationship and make it part of their experience? On the other hand, is it not the case that by treating the Infant Jesus as their imaginary friend we are imposing a term and a category on the devotees that would go completely against their own feelings and epistemological perspective? The members of the confraternity would never refer to the Infant Jesus as their imaginary friend. To them, Baby Jesus is ontologically palpable, a material embodiment of sanctity which makes it possible for them to experience certain emotions they consider important, and to regain belief in their own agency. By venerating Baby Jesus they feel needed, particularly as mothers and grandmothers.

Any description or account here must clearly begin with a reflection on why worship of the Infant Jesus in the confraternity is predominantly a female form of spirituality (only one member of the confraternity is male). ${ }^{32}$ Women manage this form of devotion, women promote it, women embody it, and women choose suitable ritual and linguistic forms of expression; they have literally taken care of the figurine, prayed over it, and made its robes. Thanks to these prayer services and the relationship they have established with the figurine, they turned it into a sacred object imbued with holiness.

Formally, to make the figurine a sacred object in accordance with Church doctrine, they needed the support of the Church hierarchy. However, the fact that the women experience direct evidence of the Child being present in their lives means that they feel independent of the men representing the Church hierarchy; the only role played by men is to give this form of worship institutional legitimacy. Interestingly, Irena seems to have been remarkably successful: worship expressed through the figurine appears to have actually dominated religious life in her church. The parish website predominantly features content related to the Infant Jesus (as provided by Irena and her assistant).

We should add that Irena and her fellow members rarely use the term "figurine." Instead, they favour the word "Dzieciątko," or the Baby. One of my respondents told me that she prays in front of the Baby, kisses it, and joined the confraternity because she loves children and wants to worship Jesus in that form. Another told me that she became a member because she wanted to worship Jesus from the earliest moments of his life, and said that being able to host Baby Jesus under one's own roof was a great gift of grace. My respondents often use diminutives such as Dzieciatko (literally “tiny

${ }^{30}$ We should add that research indicates that both children with imaginary companions and adults who feel like they talk to God consider those entities as belonging to "different epistemological category than an encounter with an actual human"; the important thing, however, is that they treat such encounters seriously - see T.M. Luhrmann, When God Talks Back. Understanding the American Evangelical Relationship with God, New York 2012, p. 80.

${ }^{31}$ Ibidem, pp. 79-80.

32 The man declined to be interviewed. 
babe") or figureczka ("tiny figurine"): the former way of looking at the figurines is coloured by affordance, or its material characteristics. ${ }^{33}$ The related affordance produces a culturally conditioned gaze.$^{34}$ This gaze is a two-way process (when the women enter a personal relationship with the Infant Jesus, and ask him for favours or give thanks), but it is also communal (when they do the same together in the church building). With this communal gaze they can experience the sacred as "collective consciousness" ${ }^{\prime 35}$ and it has a remarkable power to objectivise their relationship with the material vehicle of divine presence that mediates their contact with the sacred. They find it easier to pray to an infant Child than to a crucified Christ; they get the sense that it is almost rude to be bothering a suffering individual with their trivial problems. The figure of a Child, on the other hand, puts the praying women at ease, and helps them to articulate their personal concerns more freely.

When contemplating the figurine, some of the members seek to empathise with its infancy; for instance, they meditate on the thoughts Jesus might have had as a child. In order to gain a better understanding of Jesus's infancy, they planned to go to a screening of The Young Messiah, a 2016 movie by Cyrus Nowrasteh. They also pray to Mary for the same thing:

Mother of God! What kind of child did you give birth to? Let me hold him for just a short while so I can feel the Baby and see it, so I can understand its heart (...). As a woman, you want to touch everything with your heart, isn't that right? (MB)

This said, the members do not always think of Jesus as an infant. In their thoughts and prayers they often address him as "Lord Jesus." In practical terms, Baby Jesus appears to be an important materialisation of the sacred with which they remain in a close relationship, but this relationship does not encompass the worship of Jesus in its entirety. However, given that they have agreed to pray daily to the Infant Jesus, this infantile image becomes reinforced in their religious imagery.

Almost every single one of my female respondents had a figurine of her own at home,$^{36}$ where it was usually placed at or near the family altar. They claim that having the figurine at home makes it easier for them to remain focused in prayer. One of the women told me that one should kneel down to pray if one expects to be heard. To them, the figurine is a focal object, a material thing they gaze at to establish a kind of two-way dialogue between the beholder and the beheld in a steady gesture of attention..$^{37}$ By combining sustained prayer with that kind of gaze they achieve the "ontological inseparability of the picture from "what is represented," 38 i.e. Jesus him-

33 J. Gibson, The Ecological Approach to Visual Perception, New York-London 2015.

${ }^{34}$ Morgan defines it as a "a visual structuring of relations that organizes power as a situation in which people find themselves in relation to one another, a social body and a sacred referent"; see D. Morgan, Embodied Eye: Religious Visual Culture and the Social Life of Feeling, Berkeley 2012, p. 70.

${ }^{35}$ Ibidem, pp. 73, 78.

${ }^{36}$ Before they were able to buy their own figurines they had a shared one that the members took from house to house.

${ }^{37}$ D. Morgan, Introduction. The Matter of Belief [in:] D. Morgan, Religion and Material Culture. The Matter of Belief, London-New York 2010, pp. 10, 20.

${ }^{38}$ H.-G. Gadamer, Truth and Method, London-New York 2004, p. 134. 
self. To them, this is an important way of achieving what Morgan called a "corporeal practice of belief." 39 Their religious imagery is largely shaped by things related to the figurine, primarily meaning individual contacts and prayers taking place before the figurine, but also collective devotions in prayer services, prayer requests and testimonies, the nuns changing the figurine's robes, or the confraternity members receiving photographs of the figurine every month. Their belief in Baby Jesus is to some extent realised through sensory-based practices. ${ }^{40}$ This said, their imageries are moderated by other messages and ideas communicated and reinforced at the monthly meetings and prayer services involving the figurine, the recommended readings frequently set by Irena, and new testimonies of the Baby's miraculous interventions, which the members share with one another.

The female worshippers of the Child Jesus believe that this form of worship has a particular resonance for them at this point in their lives, and report a flourishing of their religious life after retirement. As one of the women put it, "God gives old age so that people pray." Another member spoke in similar terms:

I came to the conclusion that God gives time to everyone. He gave me mine in my retirement, and I want to use it. So, I have a lot of prayers. I get up in the morning and there's the prayer upon waking, I have my breakfast, there's a prayer for that, I go to the shops, there's a prayer for that, I get back from the shops, there's a prayer for that, and so it goes throughout the day (...). To pray is to do atonement for sins, primarily your own, but also for the sins committed by other sinners in this world.

The women also appeared to treat their religious commitment as a form of counteracting the marginalisation of older women in Polish society. ${ }^{41}$ The most active members of the confraternity ${ }^{42}$ tend to belong to several church communities simultaneously (secular Carmelite tertiaries, the Living Rosary, the Community of the Blood of Christ, The Rosary Crusade, Catholic Action, or the online group Mary Save Mankind $^{43}$ ). They only read religious literature, listen to Catholic radio, watch Catholic television programmes, go to masses that involve prayers for healing or adoration of the Blessed Sacrament, attend mass every day, and have altars at home decorated with family memorabilia and/or souvenirs from pilgrimages, as well as a figurine or picture of the Infant Jesus. Their responsibilities as members involve living a sacramental life, particularly including the taking of Holy Communion, entrusting one's life to the Infant Jesus, daily prayers including "Glory to the Father" (three times a day) and "Bless us, Divine Child Jesus" (three times a day), participation in confraternity formation meetings and prayer services (a novena on the twenty-fifth day of each month), and celebrating the so-called Jesus month (25 December). They carry

${ }^{39}$ D. Morgan, Introduction..., op. cit., p. 9.

${ }^{40}$ Ibidem, p. 11.

${ }^{41}$ J. Robbins, Challenging Marginalization at the Universities of the Third Age in Poland, "Anthropology \& Aging Quarterly" 2013, vol. 34, no. 2, p. 157.

42 Those are the women I interviewed to obtain the primary material for my article.

${ }^{43}$ One member registered on an "Atonement" website (www.pokuta.info), whose members receive text messages to pray for dying people (the messages must be responded to within three minutes to avoid removal from the group). 
membership cards, a miraculous medal and a scapular of the Infant Jesus. In particular, devotion to the Infant Jesus involves praying to the Baby to ask for gifts of grace on behalf of other people. The members also have 12 pictures of the Infant Jesus figurine dressed in different robes, which they receive from their leaders during the monthly meetings.

In addition to the required prayer times and the agreed places, the women very often pray on their own, including in mundane situations such as shopping or waiting for a bus. As one of them puts it:

When I'm walking down a street and praying, I like to think that the city is filling up with prayer. Those streets can also be steeped in prayer, so to speak. And the rosary also acts like an exorcism. When you recite your Hail Marys, you simply expel evil. (A)

The women like to discuss cases of healings which they or their loved ones experienced thanks to Baby Jesus, ${ }^{44}$ as well as the general subject of signs from heaven which give them consolation in their daily life, and provide evidence of God's love in their lives. ${ }^{45}$ They provided many examples of God intervening in their lives or in the lives of their loved ones. They often go on pilgrimages: one member went on thirteen within a single year. Among the most important pilgrimage sites they list Częstochowa in Poland and Međugorje (Medjugorje) in Bosnia and Herzegovina. Two of my respondents described Međugorje as the most beautiful place on earth, and want to visit it a second time. They also go to Polish shrines including Sokółka, Licheń, Tarnów (to visit the grave of Rozalia Celakówna, a nun and mystic), Łagiewniki or Tarnowiec (Calvary of Unborn Children), Jarosław, Łańcut or Chmielnik.

They regard their own religious involvement as a valuable part of their lives that was not available to them in their earlier lives because they had no time for prayer and religious reading, and they also see it as a way of keeping busy without inconveniencing their children or husbands (if still living). Most are no longer professionally active, and feel no obligation to spend most of their time doing household chores, and some of them are widows or their relationships with their husbands are no longer very close. To fill that gap, they give themselves the role of intermediaries praying to God for important family matters. Some pray for safe pregnancies, or ask God to help with their children's fertility issues, but they also often pray for the president or the country. They also pray to the Infant Jesus in more extreme situations, such as cancer (their own or other people's). As I mentioned, one of the women joined the confraternity (on Irena's recommendation) after experiencing a recovery from cancer. On many occasions they insisted that the Baby sends gifts of grace swiftly, and does it above and beyond what they ask for.

According to the members, this form of worship mainly appeals to women and girls, who they believe are more spiritual, and who play with dolls to prepare for their

${ }^{44}$ One respondent told me that she doesn't need to pray for herself: when she prays for her loved ones, the Baby blesses her through them.

${ }^{45}$ Based on these signs, they then find it easier to develop a sense of God's love and to believe, by which they mean having trust in God. 
future role as mothers. The figurine provokes maternal feelings in them, and they find it approachable:

Children see the Baby - look, isn't it pretty! - and women want to hug it. When men see the Baby, this is nothing special, it's just a figurine, it doesn't mean anything to them. (M)

Just as people were once unwilling to offer refuge to the Baby and its parents in Bethlehem, one of my respondents argued, so it is now a great gift of grace for her to be able to take the Baby into her house, and to keep it in a place of honour. They frequently identified tenderness as a primary emotion they felt towards the Baby.

The women's comments clearly suggest that the members find this image of Jesus particularly convincing, and it makes him more approachable, although some admit that this involved a certain learning curve. Still, they did not find it too difficult since they regard this form of spirituality as their charyzmat, i.e. their particular spiritual gift or charism. This is illustrated by the following statement:

You see, over 2000 years ago people were unwilling to accept God in the person of Baby Jesus, and that's a great gift of grace, as I realised. I realised it just this year, how much of a gift it is to be a member of the confraternity, and to adore Baby Jesus. I don't know if I do it right or wrong, but it's a great gift of grace. Over 2000 years ago people didn't want to have anything to do with Baby Jesus, but I've taken it under my roof, and learned to love Baby Jesus, I try to recite the confraternity's prayers, and I've realised that that was a major grace. $(\mathrm{J})$

I noticed that my respondents tend to conflate devotion to the Infant Jesus with their role as grandmothers. Some have gifted the figurine to their grandchildren, and are trying to encourage them to worship it. I have a strong feeling that there is a connection between their being grandmothers and their devotion to the Infant Jesus. For one thing, they predominantly pray for the health and salvation of their grandchildren; secondly, they mostly associate Baby Jesus with their grandchildren, and vice versa; finally, they regard God in the form of a two-year-old child as being more likely to hear their prayers for children, even if they perceive the Child Jesus rather as the son or intermediary who carries their prayers to God the Father, who is particularly likely to hear the prayers quickly if presented by a child. One of my respondents told me that the point of worshipping Baby Jesus was to pray with the Baby and to the Baby, which is what she does. Another emphasised the fact that the Child Jesus has more understanding for human weakness than God, who is an adult; she explained that when she craves sweets, she finds comfort in the thought that Jesus liked sweets, too, and that the Mother of God often baked gingerbread cookies for her son.

On the other hand, the figurine itself triggers maternal feelings in the women. This is arguably part of the mainstream Western Christian approach, where God is imagined as a close and unthreatening presence. In this model, God no longer provokes a sense of mysterium tremendum..$^{46}$ Accordingly, worship may only survive if its object inspires a sense of mysterium fascinans. ${ }^{47}$ The fact that they are experiencing this is borne out by stories of the advice they have received from the Baby, particularly

\footnotetext{
${ }^{46}$ R. Otto, The Idea of the Holy, transl. J. Harvey, London-Oxford-New York 1958, pp. 12-24.

${ }^{47}$ Ibidem, pp. 31-40.
} 
when seeking confirmation that they are doing the right thing, and in the stories of signs and miracles. In other words, their fascination comes from the manifestations of a power that in their eyes constitutes the supernatural and sacred status of the Infant Jesus.

One case in point is the story of a woman who was unwilling to take communion while standing up, despite a priest telling her to do so. She prayed to Jesus for light in this matter, and heard his words telling her to kneel down:

I had a case like this in the Baby's church, a priest was refusing to give me communion because I was kneeling down. I knelt down and waited, and he says to me, "In this church we only give communion in a standing position," and I said, without keeping my voice down, "But I want to receive it kneeling down!" And I waited. He gave communion to everyone, and finally to me as well. I got back to my place and thought, "Lord Jesus, am I being disobedient?" And a thought immediately popped up in my head, "Fall to your knees!" And just like that, I knew that I was on the right track. For me, this is God, the highest good, power, omnipotence, but at the same time it's love and mercy, but that's God, even the angels can't comprehend him, let alone us people! (J)

The woman mentioned more instances when she heard the voice of Christ, who reveals himself to her when she is praying in the church.

The women also mention other signs, such as events in the liturgical calendar coinciding with events in their own lives. For instance, one of the women believes that her grandson, who was born on 16 July, was saved by Our Mother of the Scapular, whose feast is celebrated on that date, from the consequences of oxygen deficiency during a difficult birth. Similarly, many major events in her life, such as joining the confraternity or the birth of another granddaughter she had been praying for, happened on the day devoted to the Infant Jesus, i.e. the twenty-fifth of a month. She sees this as undeniable proof of the fact that Jesus is protecting her and her family.

Visions that some of the women sometimes experience in the church are another sign. One of the women claimed to have experienced a "Eucharistic miracle," when she saw a Host transform itself into a slice of rye bread during Elevation. She took this to be a sign of something important. As it turned out later, her daughter was at that point giving the troubled, premature birth mentioned above. Other signs might include a sudden urge to do something for reasons which at that point remain unclear. One of the women mentioned that a female friend of hers felt a sudden urge to pray hard in front of the figurine during the night. It then turned out that her daughter had been involved in a serious car accident in the early morning of that day, and there were no casualties.

The women are fascinated by how quickly the Infant Jesus reacts to their requests, and by the very fact that God can be worshipped in this form. They see it as their duty to give testimony to the miracles they experienced thanks to the Child. Their traditional form of Catholicism, which is further reinforced by the Catholic media they consume to the exclusion of everything else, helps them bridge the gap separating them from the sacred. To treat God as an imaginary friend, as described by Luhrmann, would be incompatible with their religious habitus, and would seem blasphemous and improper. At the same time, God the Father is seen as being too remote 
and too awe-inspiring. The women need to bridge that gap because they essentially want to feel that their devotion comes from a religious experience based on a genuine relationship with God rather than the impositions of tradition. At the same time, they also want to make their form of worship part of the longue durée, which they achieve by tracing their model to the adoration of the Child by the shepherds and the Magi. In doing so, they have a sense that they are returning to a model of the sacred that goes back to the very foundations of Christianity. In this way, they foreground an understanding of Christianity as a religion in which God engages in an original act of kenosis (self-emptying or self-debasement) by coming into the world as a helpless babe: a divine-human infant. By their own admission, that first instance of kenosis is easier to stomach than the last, i.e. the Crucifixion. They prefer to pray to Baby Jesus than to the crucified Jesus. The crucified Jesus puts them to shame: they say they would feel awkward asking a suffering individual for trivial everyday things. They find it easier to open up before a Child who will listen to even the most trivial of requests:

If you love children you will open up your heart to Baby Jesus; and Baby Jesus appeals to children as well. That's the surest way, the easiest way to bring children closer to the Baby, because Jesus as an adult is it associated with suffering. But here there is joy, and that's more relatable. He likes to play with us, to be with us. (A)

The members find Comfort in the thought that many saints had a close spiritual relationship with the Infant Jesus. They mostly mention Margaret of the Blessed Sacrament and St Thérèse of Lisieux, followed by St Teresa of Ávila, St John of the Cross, Padre Pio (St Pio of Pietrelcina) and St Anthony of Padua. Among the Polish promoters of this form of worship they list Fr. Anzelm Gądek and Janina Kierocińska. This appears to be largely the effect of religious socialisation from Irena.

All of the female members made the decision to entrust one's life to Baby Jesus and to cultivate childlike virtues (the small way of St Thérèse of Lisieux) among the most vital aspects of this form of devotion. On this spiritual path, they are able to treat even the smallest gestures as an expression of worship:

The pope who canonised Teresa [St Thérèse] considered her to be the greatest saint for the Church because that way of childhood is everywhere in the Gospel, but she discovered it anew. What she said was, there's no need for me to achieve great things, it's enough that everything I do, I do it out of love for God, even the smallest thing, such as sweeping the monastery floors, or cleaning, so long as you trust God and do it out of love for God.

The sense of mysterium fascinans in the female members is based on paradoxes: on the one hand, the idea is to love Jesus and to worship him as a Child, and on the other, it is to become like a child yourself. The model is an unmistakably idealised child:

This is how it stands out, you have to imitate the childlike qualities, nurture those childlike qualities in yourself, that kind of simplicity, courage, openness. A child doesn't... A child is never false, unless it learns from its parents how to falsify things or tell lies. But children as such are very honest, straightforward, and very spontaneous, and very loving, children are emotional. In the confraternity we nurture those qualities, the simplicity in particular, and this is how we as the confraternity of the Infant Jesus stand out from other [religious] communities. (I) 
La Rocca argues that the women who worship Baby Jesus elect a path of spiritual development intended for "the least of these," i.e. for children, and by choosing selfeffacement they transform weakness into strength. ${ }^{48}$ On the one hand, they achieve self-realisation and gain agency through the symbolic imitation of children, and on the other hand they foreground their maternal abilities by imitating the paragon of Catholic femininity, i.e. the Mother of God. They want to be like children, but also, like Mary, they want to be mothers to the Child. ${ }^{49}$ They are simultaneously religious worshippers, servants, and disciples of the Infant Jesus, which often translates into their daily lives as grandmothers who learn to cultivate their inner child. This way, they can be closer to children, and do a better job fulfilling their ludic expectations:

You can't say to yourself, here I am, an adult, a wise person and so on, and still expect to return to your childhood, to try and play with a child, to crawl under tables, and to forget that you're an adult, to be a child. To get down to the level of the child and never feel superior, to treat your child as a friend. (A)

Imitating a child means on the one hand the skill of having carefree fun, where one allows oneself to forget about adult cares, and on the other hand the skill and the need to confront one's own limitations and weaknesses. One of my respondents said that her way of dealing with her weaknesses often involved speaking to Mary: "Just like you took care of Jesus, take me now, just like that tiny Jesus, helpless and uncertain where to go." Some of the women argue that it was Mary who led to them to this form of devotion, but they prefer to address the Infant Jesus directly about their problems.

On top of these similarities, the members also have similar political views - they vote for the conservative party Law and Justice, even though some of them do it unenthusiastically. Some choose this party as a "lesser evil," but they generally believe Law and Justice to be the only party capable of fulfilling Poland's destiny as a chosen nation made up of good people. In this context they quote the words of St Faustyna:

In any case, Lord Jesus said this to St Faustyna: "I chose the Polish nation, I have a special love for the Polish nation, if it stays obedient to my will I will give it gifts of grace, right? That nation will produce the spark of mercy." We are waiting for Jesus's promises about Poland to come true. There have been some prophecies that this is a chosen nation for those latter days, a nation to lead other nations. $(\mathrm{J})$

In this way, the women reproduce a messianic understanding of their own nation, a characteristic element of right-wing discourse in Poland whose roots go all the way back to the Romantic period.$^{50}$ In this view, the Poles are spiritual leaders of mankind,

${ }^{48}$ Cited in I. Kuźma, op. cit.

49 According to traditional theology, Mary only matters as the Mother of the Lord, and a person who acts jointly in his work of Salvation through her maternal love; see M. Bierca, Mistyka typu ludowego. Kobieca pobożność maryjna $w$ świetle teologii feministycznej [in:] Kobiety i religie, K. Leszczyńska, A. Kościańska (eds.), Kraków 2006, p. 120.

50 As Geneviève Zubrzycki notes, Romantic messianism offers a framework of interpretation for events and social relationships, and furnishes readymade scripts for collective representations and actions. At the same time it forms a semiotic context that focuses religious and national 
and sacred instruments of universal salvation. ${ }^{51}$ It should also be noted that although this idea had been voiced by some of Poland's twentieth-century political figures, such as Roman Dmowski, and some members of the Church hierarchy, such as Cardinal Stefan Wyszyński, who promoted the stereotype of "the Catholic Pole," my respondents seek support for this view by invoking the mystical visions of a woman, and one who reportedly received her visions from Jesus herself. These ideas appear to remain strong in Poland to this day ${ }^{52}$ but there seems to be gender variation in their cultural expression. To those women with right-wing views, religious ideas predominate over politics. To them, the visions that Jesus gave to St Faustyna matter more than the political views espoused by the likes of Roman Dmowski, and they themselves accept their role as the leaders of the nation, ${ }^{53}$ protecting its eschatological vocation as a moral example to other nations. ${ }^{54}$ They realise this vocation not through political activity, but rather through continuous prayer.

According to the female members of the confraternity, the thing that stands in the way of Polish people realising their messianic mission is Western consumerism and the materialistic attitudes it engenders. They view the rule of the centre-right Civic Platform and (now former) President Bronisław Komorowski ${ }^{55}$ as further obstacles to that mission because of what they view as its anti-life legislation:

A woman who is a Christian, a Catholic woman, a religious woman, she's not going to kill her baby regardless of why she's pregnant, because that's the rule, "Thou shalt not kill." Besides, penal law states that children are human beings from the beginning. That means she killed a child - she's a murderer. Things used to be different, but now people have this awareness. Regardless of whether a child is sick or not, that child is a human being, right? In our group there are many people who are defenders of life, and I'm sure they pray as well. (I)

To the women, the crucial step in fulfilling the nation's moral mission is protecting life from conception. They pray for this, and some of them also go through "spiritual adoption." ${ }^{56}$ Although most of the women are past childbearing age, it is apparent that their devotion to Baby Jesus makes them feel like they should protect life. Age is not a factor here. They believe that their spiritual engagement is also effective, thus reinforcing the strong Catholic perception of women's role as the givers of life and

symbols. Cf. G. Zubrzycki, The Crosses of Auschwitz. Nationalism and Religion in Post-Communist Poland, Chicago-London 2006, p. 50.

${ }^{51}$ A. Walicki, The Three Traditions in Polish Patriotism [in:] Polish Paradoxes, S. Gomułka, A. Polonsky (eds.), New York 1990, pp. 30-31.

52 This applies to younger people as well. Many nationalistic youth organisations have become active in Poland in recent years who seek to revive these ideas. Młodzież Wszechpolska [All-Poland Youth] or ONR [The Nationalist-Radical Camp] are just two examples.

${ }_{53}$ J. Robbins, Challenging..., op. cit., p. 160.

${ }^{54}$ M. Marody, S. Mandes, On Functions of Religion in Molding the National Identity of Poles, "International Journal of Sociology" 2005, vol. 35, no. 4, p. 52.

${ }_{55}$ Before the 2016 parliamentary election, Irena organised a pilgrimage to the shrine of St Andrzej Bobola in Strachocin to pray for the fatherland. She argued that President Komorowski should be refused communion because of his support for the abortion law.

56 This begins in March on the feast of St Joseph and ends on Christmas Day. 
responsible mothers and grandmothers. ${ }^{57}$ It bears reminding that this is a rather typical understanding of the female role in the Catholic tradition. According to Catholic doctrine, women "regardless of the other responsibilities always remain primarily givers of life, a fact that influences all the qualities attributed to women." ${ }^{15}$ This theology ignores biological barriers, and makes it possible for women to consider themselves as "givers of life" even where this is no longer physiologically possible.

The female members of the confraternity claim that Jesus quickly reacts to their margerytki ("daisies") or special prayers for unborn children (a practice distinct from spiritual adoption), where seven people take turns to pray for an unborn child throughout the week over a period of nine months (the seven days symbolise the seven petals of a daisy flower, and each of the seven people is responsible for reciting their prayers on a given day of the week).

The women are also strongly opposed to in vitro fertilisation (IVF), an attitude that remains unchanged even when their own children face fertility problems. Some of the women have prayed for their children not to use this method of fertilisation. In their view, the only acceptable method is "naprotechnology," an alternative approach sanctioned by the Church. They always have great faith that fertility problems can be overcome with fervent prayer:

We get a lot of requests and testimonies related to new pregnancies. Some of the thanks were really beautiful and moving: "We'd been married for ten years and we couldn't wait to be parents. When Baby Jesus came to this church we came to pray. We prayed, and soon a baby was conceived." This shows that they came here, prayed, and a pregnancy happened. The Baby gave them a baby. And people go and use IVF, which is against God's law. And I think God listens to prayers like this one. (I)

With IVF, people usurp God's prerogatives. The procedure involves selecting one embryo from several, perhaps from several dozen, to be implanted in the uterus. So as a matter of fact the baby is born at the expense of those other children who are murdered. (I)

The women also do not support contraception, their argument being that "God provided the children, and God will provide for the children" (AZ). As the confraternity's leader, Irena finds these issues so important that she completed a diploma course on family at the Catholic University of Lublin. She also believes that "Poland being ninety-odd per cent Catholic, the nation should observe God's law" (I, May 2016), meaning that IVF should not be used, and pregnancies should not be terminated under any circumstances.

This shows that caring for the family and for unborn children is a crucial element in cultivating the messianic mission of the Polish nation. To these women, devotion to the Infant Jesus arguably reconciles their need to live in accordance with Church teachings and with the right-wing organic idea of the nation, as well as the need to have agency through the giving or sustaining of life. This is a peculiar form of agency, clearly distinct from agency as understood by left-wing feminism, because this

${ }^{57}$ Ł. Zych, Kobieta $w$ kościele katolickim po soborze watykańskim drugim [in:] Kobiety i religie, op. cit., p. 38.

${ }^{58}$ Z. Radzik, Kościót kobiet, Warszawa 2015, p. 266. 
agency is ultimately not the women's own, but rather God's. Their role is to be intermediaries who intercede with Jesus, and who claim to listen to his will. ${ }^{59}$ The women put trust in Jesus with their problems, saying "Lord Jesus, lead me, I surrender myself to you," or hope for divine intervention. At the same time they find great satisfaction in the fact that Jesus chose to listen to their prayers, and are happy to share stories of his miraculous power. This confirms the valuable observation made by Jessica Robbins, that by making their own life stories part of the nation's history, these women ${ }^{60}$ reclaim their status as moral subjects in old age. As Robbins writes in an article in Polish, this narrative conflation of the personal and the national (including a crucial network of historical and geographical connections) prepares a foundation for moral agency, multi-layered bonds and intergenerational continuity. ${ }^{61}$ Prayer, and involvement in causes such as the lives of unborn children, families or the nation, are intersecting strategies that give the women a sense of agency as members of their families and of the Polish nation.

\section{Conclusions}

In retirement-age women, devotion to the Infant Jesus offers emotional and spiritual satisfaction. With a personal relationship to the Baby, they can realise their spiritual motherhood, which they experience in a strongly sensory-based form. In doing so they become like Mary, whom they regard as the paragon of womanhood since she is the Mother of God and an intermediary between God and people. The maternal aspect is brought into sharp relief by their prayers for unborn children, ${ }^{62}$ through which they preserve the power to give new life; they get the sense that their prayers sustain a life in another woman's womb. On the other hand, they see themselves as God's servants whose role is to give testimony about the Baby's assistance in their own lives, and in the lives of people they have been praying for. They emphasise their close relationship to the Baby, who always listens to their prayers, and who inspires them to seek their inner child. To my respondents, this form of worship is in some sense a remedy that makes it possible to experience old age as a period in life where one can cultivate one's motherhood and childhood as spiritual rather than biological facts. ${ }^{63}$ They want to be like mothers or grandmothers to the Baby, but they also want to become children with its help - to live a life of openness, simplicity, and humility.

59 This objectivisation occurs at the level of the socially informed body, shaped predominantly in the church by religious groups of which the women are members.

${ }^{60}$ Robbins writes about older Poles generally; see J. Robbins, “Aktywność” i jej etnograficzne konteksty: starzenie się, pamięć i podmiotowość w Polsce, "Forum Oświatowe” 2013, no. 1/49, pp. 103-119.

${ }^{61}$ Ibidem.

${ }^{62}$ At the same time, they regard praying for them to the Infant Jesus as a religious alternative to in vitro fertilisation, which they consider sinful. When a respondent's daughter experienced fertility problems she told her, "'My child, anything but IVF,' and I prayed to Jesus: 'Lord Jesus, do not allow them to use IVF.' That's how I prayed" (JC).

${ }^{63}$ E. Adamiak, Blogosławiona między niewiastami, Lublin 1997, p. 99. 
Their relationship to the figurine of the Infant Jesus, the group prayers and testimonies of miraculous interventions are factors that help to embody their worship of the Infant Jesus, and provide ontological support for their belief. On the other hand, it is the specific appearance and affordance of the figurine that makes it possible to establish a close and comfortable relationship with the sacred that it embodies.

My material demonstrates that this form of religious belief seeks full compatibility in all aspects of life, including those that spill beyond the personal and into the political. With their religious life, the women regain agency, and have a sense that their prayers release them from their biological constraints, and protect them from the existential fear caused by a sense of waning life. The practices connected with this form of devotion fill up much of their time. As "intermediaries" between the immanent and transcendent worlds they can actively participate in the life cycle of other people and, importantly to them, in the social life of the nation, which they regard as a messianic community.

In a sense, this form of devotion plays a role which is therapeutic and compensatory. In a situation in which the women's families and society at large can only offer marginal roles to the women of their generation, devotion to the Infant Jesus is a way of reclaiming one's maternal dignity, and finding a sense of being "givers of life."

Translated by Piotr Szymczak

\section{References}

Adamiak E., Błogosławiona między niewiastami, Lublin 1997.

Batog B.B., Miłość do Dzieciątka Jezus w życiu i działalności czcigodnej sługi Bożej M. Teresy Kierocińskiej [in:] Dzieciątko Jezus w Karmelu. Sesja naukowa z okazji 100. rocznicy erekcji bractwa Dzieciątka Jezus w Krakowie (25.01.2014), J.W. Gogola, Z.K. Dubel (eds.), Kraków 2014, pp. 85-120.

Bierca M., Mistyka typu ludowego. Kobieca pobożność maryjna w świetle teologii feministycznej [in:] Kobiety i religie, K. Leszczyńska, A. Kościańska (eds.), Kraków 2006.

Bourdieu P., Outline of a Theory of Practice, Cambridge 1977.

Csordas T., Body/Meaning/Healing, New York 2002.

Dzieciatko Jezus w Karmelu. Sesja naukowa z okazji 100. rocznicy erekcji bractwa Dzieciatka Jezus w Krakowie (25.01.2014), J.W. Gogola, Z.K. Dubel (eds.), Kraków 2014.

Ferko P., Mały Król Chwały z Beaune (Francja), https://www.karmel.pl/maly-krol-chwaly/ [access: 31.05.2017].

Gadamer H.-G., Truth and Method, London-New York 2004.

Gajewski B., Pikor T., Kult Dzieciatka Jezus w Golcowej, Golcowa 2014.

Gibson J., The Ecological Approach to Visual Perception, New York-London 2015.

Gogola J.W., Duchowość Dzieciątka Jezus u świętych Karmelu [in:] Dzieciątko Jezus w Karmelu. Sesja naukowa z okazji 100. rocznicy erekcji bractwa Dzieciatka Jezus w Krakowie (25.01.2014), J.W. Gogola, Z.K. Dubel (eds.), Kraków 2014, pp. 21-32.

Kapłon J., Historia kultu Dzieciatka Jezus w Jodtowej [in:] Dzieciatko Jezus w Karmelu. Sesja naukowa z okazji 100. rocznicy erekcji bractwa Dzieciatka Jezus w Krakowie (25.01.2014), J.W. Gogola, Z.K. Dubel (eds.), Kraków 2014, pp. 133-138. 
Kult Praskiego Dzieciatka Jezus, http://www.fara.rzeszow.pl/grupy-duszpasterskie/bractwo-praskiego-dzieciatka-jezus/ [access: 31.05.2017].

Kluz W., Dobre drzewo. Opowieść o Ludwiku i Zeldii Martin, rodzicach św. Teresy od Dzieciątka Jezus, Kraków 2005.

Kuźma I., Wspótczesna religijność kobiet. Antropologia doświadczenia, Poznań 2008.

Luhrmann T.M., When God Talks Back. Understanding the American Evangelical Relationship with God, New York 2012.

Maleńka miłość. Kult praskiego Dzieciatka Jezus. Modlitewnik, Kraków 2013.

Maleńka miłość. Tajemnice dziecięctwa. Zeszyty formacyjne, Rzeszów 2014.

Marody M., Mandes S., On Functions of Religion in Molding the National Identity of Poles, "International Journal of Sociology" 2005, vol. 35, no. 4, pp. 49-68.

Morgan D., Embodied Eye: Religious Visual Culture and the Social Life of Feeling, Berkeley 2012.

Morgan D., Introduction. The Matter of Belief [in:] D. Morgan, Religion and Material Culture. The Matter of Belief, London-New York 2010, pp. 1-18.

Orsi R., Material Children: Making God's Presence Real for Catholic Boys and Girls and for Adults in Relation to Them [in:] R. Orsi, Between Heaven and Earth. The Religious Worlds People Make and the Scholars Who Study Them, Princeton-Oxford 2005, pp. 73-109.

Otto R., The Idea of the Holy, transl. J. Harvey, London-Oxford-New York 1958.

Praśkiewicz S., Kult Dzieciątka Jezus w polskim karmelu reformowanym [in:] Dzieciatko Jezus w Karmelu. Sesja naukowa z okazji 100. rocznicy erekcji bractwa Dzieciatka Jezus w Krakowie (25.01.2014), J.W. Gogola, Z.K. Dubel (eds.), Kraków 2014, pp. 35-56.

Radzik Z., Kościół kobiet, Warszawa 2015.

Robbins J., "Aktywność" $i$ jej etnograficzne konteksty: starzenie się, pamięć i podmiotowość w Polsce, "Forum Oświatowe" 2013, no. 1/49, pp. 103-119.

Robbins J., Challenging Marginalization at the Universities of the Third Age in Poland, "Anthropology \& Aging Quarterly" 2013, vol. 34, no. 2, pp. 157-169.

Św. Teresa od Dzieciątka Jezus, Dzieje duszy, Kraków 1984.

Walicki A., The Three Traditions in Polish Patriotism [in:] Polish Paradoxes, S. Gomułka, A. Polonsky (eds.), New York 1990, pp. 21-39.

Zubrzycki G., The Crosses of Auschwitz. Nationalism and Religion in Post-Communist Poland, Chicago-London 2006.

Zych Ł., Kobieta w kościele katolickim po soborze watykańskim drugim [in:] Kobiety i religie, K. Leszczyńska, A. Kościańska (eds.), Kraków 2005, pp. 33-46. 